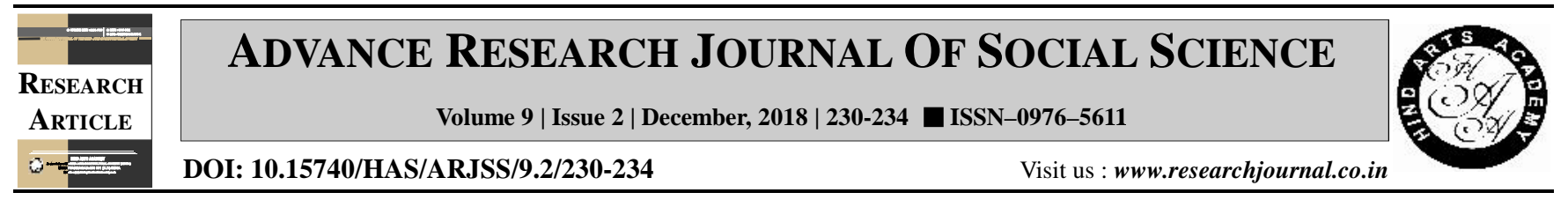

\title{
Study of social conditions and economic problems of employed women
}

Savita Patil ${ }^{1 *}$ and Haji Begum ${ }^{2}$

${ }^{1}$ Department of Sociology, Maharani Women's Arts, Commerce and Management College, Bengaluru (Karnataka) India ${ }^{2}$ Department of Sociology, Govt. Women's First Grade College, Kalburgi (Karnataka) India (Email: hajibegum@ gmail.com) Email: savitapatil14@gmail.com

\section{ARTICLE INFO :}

$\begin{array}{lll}\text { Received } & : & 15.10 .2018 \\ \text { Revised } & : & 19.11 .2018 \\ \text { Accepted } & : & 22.11 .2018\end{array}$

\section{KEY WORDS :}

Social conditions, Economic problems, Employed women

\section{HOW TO CITE THIS ARTICLE :}

Patil, Savita and Begum, Haji (2018). Study of social conditions and economic problems of employed women. Adv. Res. J. Soc. Sci., 9 (2):230-234,DOI:10. 157 40/HAS/ARJSS/9.2/230-234. Copyright@2018 : Hind Agri Horticultural Society

*Author for correspondence

\begin{abstract}
Entrepreneurship is an economic activity which is undertaken by an individual or group of individuals. Entrepreneurship can be defined as the making of a "new combination" of already existing material forces; entrepreneurship throws up as innovations, Women entrepreneurship in India represents a group of women who have broken away from the track and are exploring new vistas of economic participation. In India female work participation rate was 25.7 per cent in 2001. During $19^{\text {th }}$ and early $20^{\text {th }}$ centuries there was relatively limited use of women in textile mills. The women entrepreneurs of 1950s, 1960s and 1970's had accepted both their social and occupational roles. According to 1971 census, the total female working population was about 13.8 per cent of the total work force. In this findings, the women are in profession like tailoring and those who were the people were less educated they will not like work in some organized sector and some are taken it as the additional work. In villages, the women were most commonly working in agricultural fields, cultivation, basket making, pottery, home based products etc. but in urban areas that is in towns we can see the most of women are in tailoring jobs. The large masses were also in factory that is the organized sector.
\end{abstract}

